\title{
PEMBELAJARAN MATEMATIKA SEBAGAI MEDIA PENDIDIKAN KARAKTER
}

\author{
Ria Norfika Yuliandari \\ Universita Islam Negeri Maulana Malik Ibrahim Malang, Indonesia \\ ria.norfika@pgmi.uin-malang.com
}

\begin{abstract}
Character building recently has become a national issue that piques many people's interests. Character building is all about an effort to develop positive characters in students. Character building is relevant to develop students' positive character values in formal education. The development of students' positive character values in formal education will succeed if there is integration between the character values and themes or topics of discussion in every subject. Mathematics, as one of the most time-consuming subjects learned at school, has to be able to be designed as a media presenting the character values in character building. As a result, Mathematics will not always only emphasize on cognitive aspects, but also build positive character values. The character values included in Mathematics' learning objectives are honesty, discipline, curiosity, hard work, responsibility, creative, independence and communicativeness. To conduct Mathematic learning with the character values, there has to be compatibility among Mathematics' learning objectives, competency as written in the curricula, and the character building values.
\end{abstract}

Keyword: Learning Mathematics; Media; Character Building Copyright (C) 2017 Madrasah Jurnal Pendidikan dan Pembelajaran Dasar. All Right Reserved

\section{A. PENDAHULUAN}

Sekolah Dasar adalah jenjang paling dasar dalam pendidikan formal di Indonesia. Ketika anak sudah masuk ke dalam pendidikan formal, pada setiap tahapan perkembangannya ada tiga aspek penilaian yaitu kognitif, afektif dan psikomotorik yang menjadi acuan untuk menilai sejauh mana kemajuan perkembangan anak tersebut. Aspek kognitif menekankan pada kemampuan inteletual anak, sedangkan aspek afektif mengarah pada pembentukan perilaku positif yang kemudian populer dinamakan pendidikan karakter.

Matematika merupakan salah satu mata pelajaran yang paling banyak mendapatkan porsi jam paling lama dibandingkan dengan mata pelajaran yang lainnya. Dengan waktu pembelajaran yang lebih lama tersebut, diharapkan dapat memberikan hasil pembelajaran yang maksimal. Hasil belajar dalam ranah kognitif, misalnya, pada kenyataannya, durasi pembelajaran tidak berbanding lurus dengan hasilnya, mengingat durasi belajar matematika negara lain yang hanya 45 menit per sesi, sedangkan di Indonesia mencapai 90 menit per sesi. Menurut Maryanti (2012:4) hal ini dapat dilihat dari, misalnya, hasil penilaian Programme for International Student Assesment (PISA) yang menempatkan Indonesia pada peringkat ke 61 dari 65 negara dengan rataan skor 371, sementara rataan skor international adalah 496.

Vol. 10 No. 1, Desember 2017

Madrasah homepage: http://ejournal.uin-malang.ac.id/index.php/madrasah/index 
Dengan pertimbangan banyaknya porsi jam pembelajaran tersebut, selain diharapkan hasil pembelajaran semakin meningkat juga dapat dimanfaatkan sebagai media pendidikan karakter pada peserta didik. Prabowo dan Pramono (2010) mengatakan bahwa untuk menanamkan pendidikan karakter kepada peserta didik setidaknya membutuhkan tiga hal penting, yaitu keteladanan, pembiasaan dan koreksi/kontrol. Pendidikan karakter dianggap salah satu hal penting sebagai indikator tercapainya kompetensi sosial yang harus dikuasai peserta didik sebagai salah satu hasil belajar. Seperti hal nya pada kurikulum 2013 (2013:83) bahwa aspek sikap sosial menjadi salah satu kompetensi yang harus dikuasai dari pembelajaran. Aspek sosial ini meliputi menunjukkan perilaku jujur, disiplin, tanggungjawab, santun, peduli dan percaya diri dalam berinteraksi dengan keluarga, teman, guru, dan tetangganya serta cinta tanah air. Aspek-aspek sosial yang harus dikuasai dan dicerminkan oleh peserta didik sebagai hasil belajar dari kurikulum 2013 ini merupakan pendidikan karakter yang disampaikan oleh kemendikbud, yang bearti dalam pembelajaran hendaknya dapat digunakan sebagai wahana penyampaian karakter posititf tersebut.

Sebagai pendidik, harus paham dan mengetahui nilai-nilai karakter yang terkandung dalam pembelajaran matematika. Dengan begitu akan dapat menciptakan pembelajaran matematika yang tidak mengesampingkan nilai-nilai karakter di dalamnya. Melalui penelusuran literature, tulisan ini akan menjelaskan bahwa dalam pembelajaran matematika, nilai-nilai karakter apa saja yang dapat ditanamkan kepada peserta didik, serta bagaimana aplikasinya dalam pembelajaran.

\section{B. PEMBAHASAN}

\section{Pendidikan Karakter}

Dalam kamus lengkap Bahasa Indonesia (2003:300), menjelaskan bahwa karakter adalah sifat-sifat kejiwaan, akhlak, budi pekerti, tabiat, watak yang membedakan seseorang dari yang lain. Ini dapat diartikan secara Bahasa bahwa karakter adalah tabiat atau watak yang menjadi kebiasaan. Terdapat beberapa pendapat yang menjelaskan pengertian karakter, salah satunya adalah Maskawih (1994), yang berpendapat bahwa karakter adalah keadaan jiwa. Keadaan ini menyebabkan jiwa bertindak tanpa difikir atau dipertimbangkan secara mendalam. Selanjutnya Maskawih menjelaskan bahwa keadaan ini terdapat dua jenis yaitu yang pertama adalah keadaan alamiah yang bertolak dari watak dan keadaan yang tercipta melalui kebiasaan dan latihan. Hal ini serupa dengan pendapat Kertajaya (2010) yang menyatakan bahwa karakter adalah ciri khas yang dimiliki oleh suatu benda atau individu. Ciri khas tersebut adalah asli dan mengakar kepada kepribadian benda atau individu tersebut, serta merupakan "mesin" pendorong seseorang bertindak, bersikap, berucap dan merespon sesuatu.

Dalam kurikulum 2013, karakter ini menjadi salah satu kompetensi yang harus dicapai oleh peserta didik yang masuk pada kompetensi sikap sosial. Tentunya maksud dari sikap social pada kurikulum 2013 ini adalah sikap sosial yang positif (baik) dalam bermasyarakat. Menurut Kepmendiknas, karakter adalah sebagai nilai nilai yang khas baik (tahu nilai baik, mau berbuat baik, nyata berkehidupan baik dan berdampak baik terhadap lingkungan) yang terpatri dalam diri dan terejawantahkan dalam perilaku. Dari uraian diatas maka karakter adalah semua aplikasi nilai-nilai, kebiasaan dan perilaku yang dilakukan secara reflek dan tanpa difikir yang tercermin dalam kehidupan bermasyarakat. Sedangkan menurut ahli psikologi Lickona (1992), pengertian pendidikan karakter adalah suatu usaha yang disengaja untuk membantu seseorang sehingga ia dapat memahami, memperhatikan dan melakukan nilai-nilai etika yang inti. Selanjutnya, Lickona

Vol. 10 No. 1, Desember 2017

Madrasah homepage: http://ejournal.uin-malang.ac.id/index.php/madrasah/index 


\section{MADRASAH}

Jurnal Pendidikan dan Pembelajaran Dasar

p ISSN: 1979-5599 | e ISSN: 2502-194X

P a g e

menjelaskan bahwa karakter berkaitan dengan konsep moral (moral knowing), sikap moral (moral feeling), dan perilaku moral (moral behavior). Berdasarkan ketiga komponen ini dapat disimpulkan bahwa karakter akan terbentuk dengan baik jika didukung oleh pengetahuan tentang kebaikan, keinginan untuk berbuat baik dan selanjutnya melakukan perbuatan kebaikan, yang berikutnya akan memunculkan sebuah karakter atau watak.

Sedangkan menurut Depdiknas, pendidikan karakter adalah segala sesuatu yang dilakukan guru, yang mampu mempengaruhi karakter peserta didik. Dalam hal ini, guru dituntut untuk dapat membantu membentuk watak dan karakter anak didik. Membentuk watak ini meliputi keteladanan bagaimana perilaku guru, guru bertoleransi, guru menyampaikan materi dan hal hal lain yang terkait. Pendidikan karekter demi terwujudnya karakter bangsa dalam lingkup sekolah adalah tanggungjawab semua guru. Oleh sebab itu, pembinaan ini juga harus dilakukan oleh semua guru, bukan hanya tanggungjawab guru untuk mata pelajaran tertentu saja.

Nilai-nilai karakter yang selayaknya diajarkan kepada anak-anak adalah nilai-nilai karakter positif yang terdapat pada kehidupan bermasyarakat misalnya religius, jujur, tanggungjawab, dapat dipercaya, cinta tanah air dan lain sebagainya. Berikut ini adalah sepuluh karakter dasar manusia yang dapat dikembangkan, yang dikemukakan oleh Character Count USA sebagaimana dikutip oleh Megawangi (2004), adalah sebagai berikut: dapat dipercaya (trustworthiness), Rasa hormat dan perhatian (respect), Peduli (caring), Jujur (fairness), Tanggungjawab(responsibility), Kewarganegaraan (citizenship), Ketulusan (honesty), Berani (courage), Tekun (delligence), Integritas (integrity).

Sedangkan Kepmendiknas, melalui tim pendidikan karakter, mengemukakan bahwa terdapat beberapa nilai karakter yang harus diajarkan dalam pendidikan karakter demi terwujudnya karakter bangsa. Nilai-nilai karakter tersebut terbagi menjadi beberapa kategori, yakni:

a. Nilai karakter dalam hubungannya dengan Tuhan Yang Maha Esa (religious), diantaranya yaitu pikiran, perkataan dan tindakan seseorang yang diupayakan selalu berdasarkan pada nilai-nilai ajaran agamanya.

b. Nilai karakter dalam hubungannya dengan diri-sendiri, diantaranya jujur, bertanggungjawab, bergaya hidup sehat, disiplin, kerja keras, percaya diri, berjiwa wirausaha, berfikir logis kritis kreatif inovatif, mandiri, ingin tahu dan cinta ilmu.

c. Nilai karakter dalam hubungannya dengan sesame, meliputi sadar akan hak dan kewajiban diri dan orang lain, patuh pada aturan-aturan social, menghargai karya dan prestasi orang lain, santun dan demokratis.

d. Nilai karakter dalam hubungannya dengan lingkungan, meliputi peduli social dan lingkungan.

e. Nilai karakter dalam hubungannya dengan bangsa dan negara, meliputi nasionalis dan menghargai kebersamaan.

Nilai-nilai karakter ini, mulai tahun ajaran 2011, seluruh tingkat satuan pendidikan di Indonesia harus menyisipkan nilai-nilai karakter ini dalam proses pembelajarannya. Terdapat 18 nilai karakter dalam pengembangan pendidikan budaya dan karakter bangsa yang dibuat oleh Pendidikan Nasional, antara lain adalah: Religius, Jujur, Toleransi, Disiplin, Kerja keras, Kreatif, Mandiri, Demokratis, Rasa ingin tahu, Semangat kebangsaan, Cinta tanah air, Menghargai prestasi, Bersahabat/komunikatif, Cinta damai, Gemar membaca, Peduli lingkungan, Peduli Sosial, Tanggungjawab.

Vol. 10 No. 1, Desember 2017

Madrasah homepage: http://ejournal.uin-malang.ac.id/index.php/madrasah/index 
Nilai-nilai karakter ini mempunyai tujuan untuk meningkatkan mutu pendidikan yang meliputi penyelenggaraan dan hasilnya ke yang lebih baik. Peningkatan ini termasuk dalam hal pencapaian pembentukan karakter peserta didik yang sesuai dengan standart kompetensi lulusan. Pendidikan karakter diupayakan untuk dapat membantu peseta didik memahami, peduli dan berperilaku sesuai nilai-nilai etika yang berlaku. Sehingga diharapkan, hasil belajar peserta didik tidak hanya terbatas pada aspek kognitif saja tetapi juga diharapkan mempunyai kompetensi sikap sosial yang baik melalui pendidikan karakter ini.

Terdapat beberapa cara untuk dapat membelajarkan pendidikan karakter ini kepada peserta didik. Cara yang paling dasar, misalnya dalam pembelajaran, guru dapat memberikan contoh langsung yang dapat ditiru atau diteladani oleh peserta didik. Contoh langsung ini dapat berupa perilaku dan tingkah laku guru saat di sekolah, terutama didalam kelas. Cara yang lain yaitu menyisipkan nilai-nilai karakter dalam proses pembelajaran, misal, nilai karakter jujur dan dapat dipercaya terbentuk pada saat ujian atau ulangan tidak mencontek. Nilai karakter religius, dengan cara berdoa sebelum dan sesudah pelajaran. Nilai karakter kreatif dan kerja keras dapat diajarkan pada saat siswa mengerjakan soal cerita. Kegiatan ekstrakurikuler yang selama ini banyak dilaksanakan di sekolah juga merupakan kegiatan yang potensial untuk pembinaan karakter anak didik. Melalui kegiatan ini, diharapkan dapat meningkatkan dan mengembangkan kemampuan dan rasa tanggungjawab sosial, serta potensi dan prestasi akademik.

Banyak ahli yang mengungkapkan cara penyampaian pendidikan karakter disekolah, salah satunya adalah Paul Suparno, seperti yang dikutip oleh Zubaedi (2011:243245) yang menyatakan ada empat cara penyampaian pendidikan karakter di sekolah, yaitu:

a. Sebagai mata pelajaran tersendiri. Dalam hal ini, pendidikan karakter dijadikan mata pelajaran tersendiri yang kedudukannya dan perlakuannya sama dengan mata pelajaran yang lainnya.

b. Terintegrasi dalam semua bidang ilmu. Pendekatan ini, dalam penyampaiannya terintegrasi dalam setiap mata pelajaran, dipilih materi pendidikan karakter yang sesuai dengan tema dan pokok bahasan pelajaran.

c. Di luar pengajaran. Penguatan nilai dalam model ini lebih mengutamakan pengolahan dan penanaman nilai melalui suatu kegiatan yang memuat nilai-nilai karakter. Model ini tidak terstruktur dalam kerangka pendidikan dan pengajaran disekolah.

d. Model gabungan. Menggunakan gabungan antara model terintegrasi dan model di luar pengajaran.

Berdasarkan pendapat diatas, pendidikan karakter tidak hanya dapat disampaikan dengan cara khusus misalnya dengan dibuat mata pelajaran tersendiri, karena untuk menanamkan pendidikan karakter tidak dapat dengan cara memberikan teori mengenai karakter, tetapi akan lebih bermakna jika menanamkannya dengan cara membiasakan peserta didik melihat dan melakukan nilai-nilai karakter yang dilakukan oleh anggota sekolah. Sehingga dapat ditiru dan diteladani oleh peserta didik. Penanaman pendidikan karakter juga dapat melalui integrasi dalam setiap mata pelajaran. Misalnya dalam pembelajaran matematika dapat dipilih nilai-nilai karakter yang dapat disisipkan dengan tema dan pokok bahasan pelajaran. Semua ini dapat disimpulkan bahwa pendidikan karakter dapat diterapkan kepada peserta didik dengan pembiasaan dan teladan serta harus ada control/koreksi.

Vol. 10 No. 1, Desember 2017

Madrasah homepage: http://ejournal.uin-malang.ac.id/index.php/madrasah/index 


\section{MADRASAH}

Jurnal Pendidikan dan Pembelajaran Dasar

p ISSN: 1979-5599 | e ISSN: 2502-194X

P a g e

\section{Pembelajaran Matematika di Sekolah Dasar}

Menurut Muhsetyo (2007:26) pembelajaran matematika adalah proses pemberian pengalaman belajar kepada peserta didik melalui serangkaian kegiatan yang terencana sehingga peserta didik memperoleh kompetensi tentang bahan matematika yang dipelajari. Proses pemberian pengalaman belajar matematika untuk jenjang sekolah harus sesuai dengan karakteristik peserta didik. Hal ini yang harus dikuasi oleh seorang guru, sebelum mengajarkan mata pelajaran tersebut. Selain harus memahami karakteristik peserta didik, guru juga harus dapat memahami obyek/konten yang akan diajarkan. Anak pada usia sekolah dasar berada pada usia 7 sampai dengan 12 tahun. Rentang umur 7 sampai 12 tahun ini berada pada tahap operasional konkret. Hal ini dapat diartikan bahwa, peserta dapat berfikir logis dengan bantuan benda-benda nyata di sekitarnya, belum mampu berfikir deduktif dan masih berfikir transitif. Hal ini berbeda jika guru mengajar tingkat menengah, yang mana karakteristik peserta didiknya berbeda dengan tingkat dasar.

Menurut Prihandoko (2006:21) tujuan dari pembelajaran matematika ini adalah melatih dan menumbuhkan cara berfikir sistematis, logis, kritis, kreatif dan konsisten serta mengembangkan sikap gigih dan percaya diri dalam menyelesaikan masalah. Prihandoko juga berpendapat bahwa tujuan dari pembelajaran matematika di sekolah dasar adalah memberikan bekal yang cukup bagi siswa untuk menghadapi materi-materi matematika pada tingkat pendidikan lanjutan. Agar tujuan pembelajaran matematika ini tercapai maka salah satunya adalah kemampuan guru memilih model dan media yang sesuai dengan materi yang di ajarkan. Sedangkan dalam kurikulum tahun 2013 (2013:84), tujuan pembelajaran matematika dirangkum dalam 4 (empat) kompetensi inti, yaitu kompetensi sikap spiritual, kompetensi sikap sosial, kompetensi pengetahuan dan kompetensi ketrampilan.

Menurut pendapat Suwangsih dan Tiurlina (2006), dalam pembelajarannya, matematika pada jenjang sekolah dasar mempunyai beberapa ciri-ciri pembelajaran, yaitu pembelajaran matematika menggunakan metode spiral, pembelajaran matematika bertahap, pembelajaran matematika menggunakan metode induktif, pembelajaran matematika menganut kebenaran konsistensi, pembelajaran matematika bermakna. Ciri yang paling menonjol adalah pembelajaran matematika bersifat bertahap. Maksud dari bertahap ini adalah pembelajaran matematika dimulai dari yang paling mudah ke yang paling sulit. Selain itu, bertahap juga diartikan, dalam pembelajaran matematika dimulai dari hal konkret, semi abstrak dan abstrak. Tahapan ini mengingatkan pada tahapan belajar pada teori Bruner, yaitu tahap enaktif, iconic dan simbolik. Mengingat bahwa anak usia sekolah dasar dapat berfikir logis dengan bantuan benda-benda nyata, hal ini mempunyai kesamaan dalam hal pendidikan karakter. Contoh langsung dan nyata dari keduanya akan membantu peserta didik untuk dapat memahami dan menerapkan pengetahuan matematika dan nilai-nilai karakter.

\section{Pembelajaran Matematika dan Nilai-Nilai Karakter Bangsa}

Dalam kurikulum 2013, terdapat empat kompetensi yang harus dicapai oleh peserta didik tingkat sekolah dasar sebagai hasil belajar di pendidikan formal. Kompetensi tersebut salah satunya adalah kompetensi sikap sosial. Kompetensi sikap social ini didapatkan melalui pendidikan karakter. Matematika sebagai salah satu mata pelajaran yang mempunyai porsi jam pelajaran paling banyak, diharapkan dapat memberikan kontribusi

Vol. 10 No. 1, Desember 2017

Madrasah homepage: http://ejournal.uin-malang.ac.id/index.php/madrasah/index 
yang berbanding lurus terkait pendidikan karakter peserta didik. Pembelajaran matematika mempunyai beberapa tujuan, tujuan ini disampaikan oleh Sumarmo (2011), yaitu:

a. Memahami konsep matematika, menjelaskan keterkaitan antar konsep dan mengaplikasikan konsep atau algoritma secara luwes, akurat, efisien dan tepat dalam pemecahan masalah.

b. Menggunakan penalaran pada pola dan sifat, melakukan manipulasi matematika dalam membuat generalisasi, menyusun bukti atau menjelaskan gagasan dan pernyataan matematika.

c. Mengembangkan kemampuan memecahkan masalah.

d. Mengkomunikasikan gagasan dengan simbol, table, diagram atau media lain untuk memperjelas keadaan atau masalah.

e. Memiliki sikap menghargai kegunaan matematika dalam kehidupan, sikap rasa ingin tahu, perhatian dan minat dalam mempelajari matematika, serta sikap ulet dan percaya diri dalam pemecahan masalah.

Jika diperhatikan, pada point (1) sampai dengan (4) tujuan mengarah pada ranah kognitif yang menggambarkan kompetensi dan kemampuan berfikir matematik, sedangkan pada point (5), tujuan pembelajaran lebih mengarah pada ranah afektif yang harus dikuasai saat pembelajaran matematika. Tujuan pembelajaran dalam ranah afektif memuat nilai-nilai karakter diantaranya sikap menghargai, rasa ingin tahu, perhatian dan minat, ulet serta percaya diri. Tetapi pada kenyataannya mungkin sebagian besar masih mengutamakan kemampuan kognitif daripada kemampuan afektif. Hal ini yang bisa saja yang membuat wajah pendidikan di negara kita sangat mungkin mencapai kecerdasan kognitif yang tinggi tetapi tidak mencerminkan nilai nilai karakter yang baik dalam pergaulan sehari-hari.

Dalam kurikulum 2013, pendidikan karakter menjadi fokus dengan tujuan mengubah peserta didik menjadi lebih santun dengan pendidikan karakter. Astuti (dalam Suara Merdeka 24 Maret 2014) menerangkan bahwa kurikulum 2013 memiliki empat kompetensi inti, yakni kompetensi inti 1 (KI 1) yang berisi tentang nilai-nilai religius, KI 2 berisi nilai-nilai sosial kemanusiaan, KI 3 berisi pengetahuan, dan KI 4 berisi proses pembelajaran. Dalam KI 1 dan KI 2 tidak ada materi yang diajarkan tetapi menjadi semangat dalam setiap mata pelajaran yang diajarkan. Contoh, KI 1 dalam mata pelajaran matematika misalnya, seorang guru dituntut mengajarkan siswa bagaimana cara menghargai matematika karena sangat berguna dalam kehidupan sehari-hari misalnya membaca jam untuk mengingat waktu sholat. . KI 2 bertujuan mengubah pembelajar menjadi pribadi yang bersikap baik. Nilai-nilai kejujuran, disiplin, dan tanggung jawab serta peduli harus ditanamkan sejak dini kepada pembelajar.

Untuk mendapatkan tujuan pembelajaran matematika yang seimbang antara ranah kognitif dan afektif, maka harus ada kesetaraan antara nilai-nilai dalam pendidikan karakter dengan tujuan pendidikan matematika dan disposisi matematik. Berikut ini akan disajikan table yang menjelaskan hal tersebut yang dikutip dari Sumarmo (2011).

Vol. 10 No. 1, Desember 2017

Madrasah homepage: http://ejournal.uin-malang.ac.id/index.php/madrasah/index 


\section{MADRASAH}

Jurnal Pendidikan dan Pembelajaran Dasar

p ISSN: 1979-5599 | e ISSN: 2502-194X

P a g e

Tabel B.1 Kesetaraan Nilai-Nilai Dalam Pendidikan Karakter Dengan Tujuan Pendidikan Matematika Dan Disposisi Matematik Serta Ilustrasi Suasana Pembelajaran.

\begin{tabular}{|c|c|c|c|}
\hline No. & & lai Nilai Dalam & $\begin{array}{c}\text { Ilustrasi Suasana Pendidikan Karakter } \\
\text { Dalam Pembelajaran Matematika }\end{array}$ \\
\hline
\end{tabular}

1. Religius Beriman dan bertaqwa kepada Dengan memandang kelas sebagai Tuhan Yang Maha Esa.

\begin{tabular}{lll}
\hline 2. & Jujur & Berakhlak mulia, jujur, \\
d. & Disiplin & disiplin, dan tanggungjawab. \\
\cline { 1 - 2 } & Toleransi &
\end{tabular}
masyarakat belajar, guru menciptakan suasana religious selama pembelajaran. Misalnya melalui pembiasaan dan teladan, guru berbahasa santun, bersyukur dan berdoa, menghargai agama dan budaya masing masing. Melalui pembiasaan dan keteladanan, guru bersifat jujur, disiplin dan tanggungjawab dalam melaksanakan pembelajaran, dalam bekerja dan menilai tugas, ulangan/ujian dan menyusun karya ilmiah dengan mengikuti aturan/teorema matematik yang berlaku dan mendorong siswa menerima perbedaan kemampuan.

\begin{tabular}{lll}
\hline 6. & Menghargai & Mengapresiasi peran \\
& prestasi & $\begin{array}{l}\text { matematika dalam kultur dan } \\
\text { nilai, matematika sebagai alat } \\
\text { dan Bahasa dan kegunaan } \\
\text { matematika dalam kehidupan. }\end{array}$ \\
& & $\begin{array}{l}\text { Bekerja dengan cakap, } \\
\text { bergairah dan berfikir secara } \\
\text { akurat, efisien dan tepat. }\end{array}$
\end{tabular}

Melalui pembiasaan dan keteladanan, guru menghargai pendapat, hasil karya orang lain, keindahan, peran dan manfaat matematika sebagai alat dan sebagai Bahasa dalam kehidupan.

Sebagai pendidik, motivator, fasilitator dan manager belajar, melalui pembiasaan dan keteladanan, guru bekerja dengan cakap, akurat, efisien dan tepat, membimbing siswa belajar aktif, berfikir logis, menyajikan masalah yang menantang yang berkenaan dengan pemahaman, penalaran, dan menemukan ide.

\begin{tabular}{lll}
\hline 8. Kreatif & $\begin{array}{l}\text { Sikap lentur, luwes, kritis, dan } \\
\text { kreatif, misalnya mencipta, } \\
\text { berkhayal dan berinovasi. }\end{array}$ & $\begin{array}{l}\text { Melalui pembiasaan dan keteladanan, } \\
\text { guru melaksanakan pembelajaran dan } \\
\text { menyelesaikan tugas matematika } \\
\text { dengan kreatif dan lentur menyelidiki }\end{array}$ \\
& gagasan matematik, berusaha mencari \\
& beragam cara untuk menyelesaikan \\
& masalah matematika, mendorong \\
& pengembangan daya matematik berfikir \\
& secara kolaboratif; membelajarkan siswa \\
& cara bertanya dan bukan cara menjawab,
\end{tabular}

Vol. 10 No. 1, Desember 2017

Madrasah homepage: http://ejournal.uin-malang.ac.id/index.php/madrasah/index 


\begin{tabular}{ccc}
\hline No. & Nilai Nilai Dalam & Ilustrasi Suasana Pendidikan Karakter \\
Dalam Pembelajaran Matematika \\
$\begin{array}{ccc}\text { Pendidikan } \\
\text { Karakter }\end{array}$ & $\begin{array}{c}\text { Tujuan Pend. Nasional Pemb. } \\
\text { Mat. Dan Disposisi } \\
\text { Matematika }\end{array}$ & \\
\hline & & \\
\hline
\end{tabular}

keterkaitan antara konsep dan berfikir multi persfektif.

\begin{tabular}{ll}
\hline 9. Mandiri & $\begin{array}{l}\text { Sikap percaya diri, mandiri, } \\
\text { dan cendering memonitor dan } \\
\text { menilai penalaran sendiri. }\end{array}$
\end{tabular}

Melalui pembiasaan dan keteladanan, guru bersikap percaya diri dan mandiri dalam hal melaksanakan pembelajaran dan menyelesaikan tugas matematik, berkebiasaaan memonitor dan menilai penalaran sendiri, mengikuti cara berfikir siswa, memberi peluang siswa berbuat sesuai dengan jalan pikirannya, membantu siswa menetapkan standart dan bekerja dalam pandangan positif untuk masa depan.

\begin{tabular}{ll}
\hline 10. Rasa ingin tahu & $\begin{array}{l}\text { Menunjukkan sikap rasa ingin } \\
\text { tahu dalam belajar }\end{array}$
\end{tabular}
matematika.

\begin{tabular}{ll}
\hline 11. Gemar & $\begin{array}{l}\text { Menunjukkan sikap senang, } \\
\text { membaca }\end{array}$ \\
& $\begin{array}{l}\text { perhatian dan minat belajar } \\
\text { matematika. }\end{array}$
\end{tabular}

Melalui pembiasaan dan keteladanan guru menunjukkan perhatian dan minat dalam melaksanakan pembelajaran dan belajar matematika dengan memanfaatkan berbagai sumber, memberi tugas latihan kepada siswa

12. Bersahabat/ Berbagi pendapat, berfikir dan dengan memanfaatkan berbagai sumber. komunikatif berkomunikasi secara jelas dan Melalui pembiasaan dan teladan guru tepat, melalui Bahasa matematik yang tepat. berbahasa santun dan berkomunikasi secara jelas dan tepat, memperkenalkan notasi dan Bahasa matematika dengan tepat, menyajikan informasi, menjelaskan isu, membuat model, menjalin kerjasama antar guru untuk memajukan program matematika.

\begin{tabular}{lll}
\hline 13. & $\begin{array}{l}\text { Peduli } \\
\text { lingkungan }\end{array}$ & $\begin{array}{l}\text { Menerapkan matematika } \\
\text { dalam bidang studi lain dan } \\
\text { kehidupan sehari-hari. }\end{array}$
\end{tabular}
Melalui pembiasaan dan teladan, guru menerapkan matematika dalam bidang studi lain atau dalam kehidupan seharihari, mengkaitkan konsep matematika sesuai dengan konteks yang relevan, meyeleksi topik-topik matematika dalam kurikulum secara fleksibel.

\begin{tabular}{ll}
\hline 15. Demokrasi & $\begin{array}{l}\text { Menjadi warga negara yang } \\
\text { demokratis serta } \\
\text { bertanggunjawab. }\end{array}$
\end{tabular}

Melalui pembisaan dan teladan, guru bersikap demokratis dan tanggungjawab, memberikan kesempatan yang sama kepada siswa untuk merespon dan bertanya selama pembelajaran dan belajar kooperatif dalam kelompok kecil, melayani siswa sesuai dengan minat, kekuatan, harapan dan kebutuhan masing-masing, membangun masyarakat belajar dengan 


\section{MADRASAH}

Jurnal Pendidikan dan Pembelajaran Dasar

p ISSN: 1979-5599 | e ISSN: 2502-194X

P a g e

43

\begin{tabular}{|c|c|c|c|}
\hline \multirow[t]{2}{*}{ No. } & \multicolumn{2}{|c|}{ Nilai Nilai Dalam } & \multirow{2}{*}{$\begin{array}{c}\text { Ilustrasi Suasana Pendidikan Karakter } \\
\text { Dalam Pembelajaran Matematika }\end{array}$} \\
\hline & $\begin{array}{l}\text { Pendidikan } \\
\text { Karakter }\end{array}$ & $\begin{array}{c}\text { Tujuan Pend. Nasional Pemb. } \\
\text { Mat. Dan Disposisi } \\
\text { Matematika }\end{array}$ & \\
\hline & & & $\begin{array}{l}\text { kerjasama dan urunan tanggungjawab } \\
\text { dan pehatian. }\end{array}$ \\
\hline 16. & Cinta tanah air & \multirow{3}{*}{$\begin{array}{l}\text { Menjadi warga negara yang } \\
\text { demokratis serta } \\
\text { bertanggunjawab. }\end{array}$} & \multirow{3}{*}{$\begin{array}{l}\text { Melalui pembiasaan dan teladan guru } \\
\text { menciptakan lingkungan belajar yang } \\
\text { aman, berpartisipasi dalam berbaga } \\
\text { kegiatan matematika dan lainnya pada } \\
\text { tingkat nasional maupun internasiona } \\
\text { dengan membawa nama baik bangsa } \\
\text { dan negara. }\end{array}$} \\
\hline 17. & Cinta damai & & \\
\hline 18. & $\begin{array}{l}\text { Semangat } \\
\text { kebangsaan }\end{array}$ & & \\
\hline
\end{tabular}

Dari penjelasan di atas, dapat simpulkan bahwa suatu hal yang mustahil jika pendidikan karakter ini dilaksanakan tanpa melalui pembiasaan dan keteladanan. Jika hal ini dilakukan dengan sadar, komitmen dan konsisten maka akan dapat menumbuhkan dan meningkatkan nilai-nilai karakter siswa. Prinsip serupa juga terlihat pada salah satu pendekatan pembelajaran matematika, yaitu pendekatan PMRI (Pendidikan Matematika Realistic Indonesia). Agung prabowo dan pramono Sidi (2010), berpendapat bahwa pendekatan PMRI merupakan salah satu pendekatan dalam pembelajaran matematika yang jika dilakukan sebagai upaya sadar dan terrencana melalui pembiasaan dengan konsisten, kontinu dan konsekuen diyakini akan dapat menumbuhkan dan memahatkan karakter-karakter seperti kemandirian, demokrasi, toleransi, humanisme dan kejujuran. Peluang untuk memahatkan karakter-karakter tersebut menjadi dimungkinkan karena paradigma pembelajaran PMRI seperti yang dapat dicermati melalui landasan filosofis, prinsip dan karakteristiknya menjamin bahwa PMRI sangat potensial dalam menumbuhkan dan memahatkan karakter-karakter tersebut. Karakter.

Berikut ini akan disajikan Tabel Dukungan Pendekatan PMRI pada Pengembangan

Tabel B.2 Dukungan Pendekatan PMRI pada Pengembangan Karakter

$\begin{array}{cc}\text { Landasan (L), Prinsip (P) dan } & \text { Karakter } \\ \text { Karakteristik (K) PMRI (RME) } & \end{array}$

L1: mathematics must be connected to reality

interes (minat yang kuat), apresisasi dan

penghargaan terhadap matematika

\begin{tabular}{ll}
\hline $\begin{array}{l}\text { L2: mathematics should be seen as a human } \\
\text { activity }\end{array}$ & humanis \\
\hline $\begin{array}{l}\text { P1: guided reinvention through progressive } \\
\text { mathematization }\end{array}$ & motivasi \\
\hline P2: didactical phenomenology & - \\
\hline & $\begin{array}{l}\text { keyakinan, kepercayaan diri, keberanian } \\
\text { mempertahankan pendapat, bertanggung } \\
\text { P3: self-developed or emergent models }\end{array}$ \\
& $\begin{array}{l}\text { jawab, bersepakat dan menerima pendapat } \\
\text { teman }\end{array}$ \\
\hline
\end{tabular}

Vol. 10 No. 1, Desember 2017

Madrasah homepage: http://ejournal.uin-malang.ac.id/index.php/madrasah/index 


\begin{tabular}{|c|c|}
\hline $\begin{array}{l}\text { K1: phenomenological exploration or the use } \\
\text { of contexts }\end{array}$ & - \\
\hline $\begin{array}{l}\text { K2: the use of models or bridging by vertical } \\
\text { instruments }\end{array}$ & $\begin{array}{l}\text { kejujuran, kemandirian, kegigihan, dan kerja } \\
\text { keras }\end{array}$ \\
\hline $\begin{array}{l}\text { K3: the use of students own productions and } \\
\text { constructions or students contribution }\end{array}$ & $\begin{array}{l}\text { kerja cerdas, keberanian dan kemauan } \\
\text { berbagi hasil pemikirannya }\end{array}$ \\
\hline $\begin{array}{l}\text { K4: the interactive character of the teaching } \\
\text { process or interactivity }\end{array}$ & $\begin{array}{l}\text { interaksi, negosiasi, kerjasama, demokratis, } \\
\text { toleransi, antusiasme, berbagi dan } \\
\text { berdiskusi dengan sesama siswa atau guru, } \\
\text { guru menjadi teladan (panutan dan idola) }\end{array}$ \\
\hline $\begin{array}{l}\text { K5: the intertwining of various learning } \\
\text { strands. }\end{array}$ & (1 \\
\hline
\end{tabular}

\section{PENUTUP}

\section{Kesimpulan}

Dalam proses pembelajaran matematika, terdapat beberapa nilai-nilai karakter yang terkandung didalamnya. Untuk memaksimalkan tujuan pembelajaran matematika, maka guru harus dapat menyampaikan pembelajaran baik kompetensi matematiknya maupun nilai-nilai karakter didalamnya. Nilai-nilai karakter yang terkandung didalam tujuan pembelajaran matematika diantaranya adalah sebagai berikut:

a. Disiplin dan tanggungjawab. Karakter disiplin akan terbentuk saat mempelajari matematika, karena dalam matematika harus dapat memahami aturan-aturan dan konsep-konsep yang telah disepakati dan tidak boleh dilanggar. Nilai karakter yang diharapkan adalah peserta didik dapat disiplin tertib dan teratur dalam menggunakan aturan-aturan tertentu. Sikap disiplin ini akan melahirkan sikap tanggungjawab atas pelaksanaan kewajiban yang harus dilaksanakan. Contoh aplikasinya nilai karakter disiplin:

1) Guru membiasakan siswa untuk disiplin mematuhi urutan operasi pada bilangan bulat, yaitu perkalian, pembagian, penjumlahan dan pengurangan.

2) Guru membiasakan siswa agar mengerjakan tugas/PR yang diberikan oleh guru, dengan cara memberikan award dan punishment.

b. Jujur. Matematika adalah ilmu deduktif dan tidak menerima generalisasi berdasarkan pengamatan dan harus melalui bukti. Walaupun dalam tahap sekolah dasar, pemberian contoh dan ilustrasi geometris diperlukan. Nilai karakter yang diharapkan terbentuk adalah peserta didik menjadi seorang yang dapat dipercaya. Contoh aplikasi nilai karakter jujur:

1) Guru memberikan teladan kepada siswa dengan cara memberikan penilaian ulangan/tugas kepada siswa secara jujur sesuai dengan bukti yang ada.

c. Kerja keras. Dalam belajar matematika, akan lebih banyak dihadapkan pada perhitungan matematis, sehingga harus teliti, cermat, tekun dan ulet serta telaten dalam memahami. Karakter yang diharapkan terbentuk dalam proses ini adalah jiwa kerja keras, tidak mudah putus asa dan sabar. Contoh aplikasi nilai karakter kerja keras:

1) Guru membiasakan menyajikan soal-soal matematika yang menantang sehingga siswa bekerja keras dan diikuti dengan ketelitian saat menyelesaikan soal tersebut.

d. Mandiri dan percaya diri. Dalam belajar matematika akan lebih banyak dihadapkan dengan permasalahan matematika yang membutuhkan penyelesaian. Karakter yang diharapkan adalah peserta didik mempunyai jiwa mandiri dan tidak bergantung pada orang lain saat menyelesaikan masalah matematika. Selain itu juga mempunyai sifat

Vol. 10 No. 1, Desember 2017

Madrasah homepage: http://ejournal.uin-malang.ac.id/index.php/madrasah/index 


\section{MADRASAH}

Jurnal Pendidikan dan Pembelajaran Dasar

p ISSN: 1979-5599 | e ISSN: 2502-194X

P a g e

percaya diri dengan jawaban yang dihasilkan. Contoh aplikasi nilai karakter mandiri dan percaya diri:

1) Guru membiasakan memberikan peluang kepada peserta didik untuk bekerja sesuai dengan jalan pikirannya dan guru hanya bersikap sebagai fasilitator dan motivator.

2) Guru membiasakan siswa untuk maju ke depan kelas atau bertanya untuk menumbuhkan sikap percaya diri.

3) Guru membiasakan siswa dengan berbagai macam tugas, baik kelompok maupun individu untuk menumbuhkan sikap mandiri.

e. Rasa ingin tahu dan gemar membaca. Salah satu ciri pembelajaran matematika bersifat spiral yaitu saling materi yang saling berhubungan, ini diharapkan dapat memunculkan rasa ingin tahu dan mengakibatkan seseorang terus belajar dan menggali informasi-informasi terkait. Selain itu juga dapat menumbuhkan sifat gemar membaca. Contoh aplikasi nilai karakter rasa ingin tahu dan gemar membaca:

1) Guru membiasakan pembelajaran menggunakan model pembelajaran atau alat peraga yang menyenangkan siswa.

2) Guru membiasakan memberikan tugas kepada siswa yang memanfaatkan berbagai sumber.

f. Kreatif. Seorang peserta didik jika terbiasa dihadapkan pada permasalahan matematik dan dapat menyelesaikannya, maka akan muncul sikap kreatif untuk menyelesaikan masalah tersebut. Hal ini membantu peserta didik menjalani kehidupan sehari-hari dengan efektif dan efisien. Contoh aplikasi nilai karakter kreatif:

1) Guru membimbing siswa untuk mencari beragam cara dalam menyelesaikan masalah.

g. Komunikatif. Matematika adalah suatu Bahasa, sehingga seseorang harus mengkomuniksikannya dengan tepat baik secara lisan maupun tulisan, sehingga informasi yang disampaikan dapat dipahami orang lain. Contoh aplikasi nilai karakter komunikatif:

1) Guru memberikan tauladan bagaimana berkomunikasi dengan santun dan jelas kepada orang lain.

2) Guru menyampaikan materi, notasi matematika dengan tepat dan mudah dimengerti oleh siswa.

h. Peduli lingkungan dan peduli sosial. Dalam pembelajaran matematika akan banyak disajikan soal-soal tidak rutin, misalnya soal cerita. Dalam soal cerita tersebut akan banyak menggunakan konteks kehidupan sehari-hari. Dengan konteks kehidupan sehari-hari yang positif, secara tidak sadar akan menanamkan sikap peduli social dan lingkungan. Contoh aplikasi nilai karakter peduli lingkungan dan social:

1) Guru membiasakan menerapkan atau mengaplikasikan konsep matematika dengan masalah dalam kehidupan sehari-hari.

2) Guru mengkaitkan matematika dengan bidang studi lainnya.

\section{Saran}

Dari kesimpulan di atas, maka saran yang dapat disampaikan adalah:

a. Pendidikan karakter dapat disampaikan melalui pembiasaan dan keteladanan serta harus ada control dalam pelaksanannya. Tanpa pembiasaan dan keteladanan, 
pendidikan karakter akan seperti angin lalu karena pendidikan karakter tidak dapat disampaikan dalam bentuk materi saja.

b. Guru matematika sebagai pendidik harus mampu menciptakan pembelajaran yang tidak hanya meningkatkan intelutual anak dan mengesampingkan nilai-nilai karakter. Bagaimanapun peserta didik mempunyai hak mendapatkan pendidikan karakter dari sekolah terutama guru. Dari semua nilai karakter tidak harus semua dapat disampaikan secara bersamaan lewat pembelajaran matematika, dalam satu proses pembelajaran dapat memuat beberapa nilai karakter.

c. Nilai-nilai karakter dalam pembelajaran matematika ini diharapkan dapat dirangkum dalam design pembelajaran matematika yang dapat diterapkan dalam kegiatan belajar mengajar, misal dikembangkan dalam bentuk RPP.

\section{REFERENSI}

Astuti, Tri Marhaeni Pudji. (2013). Kurikulum 2013 Tekankan Perubahan Sikap Pelajar. Suara Merdeka tanggal 24 Maret 2014

Kamus lengkap Bahasa Indonesia. (2003). Tim Bahasa Pustaka Agung Harapan.

Kurikulum 2013.

Maryanti, E. (2012). Peningkatan Litersi Matematis Siswa Melalui Pendekatan Metacognitif Guidance (Thesis pada Jurusan Pendidikan Matematika UPI Bandung: tidak diterbitkan, 2012).

Maskawih. (1994). Menuju Kesempurnaan Akhlak. Bandung: Mizan

Muchlas Samani Dan Hariyanto. 2012. Konsep Dan Model Pendidikan Karakter. Bandung: Pt Remaja Rosda Karya.

Muhsetyo, Gatot, dkk. (2007). Pembelajaran Matematika SD. Jakarta: Universitas Terbuka.

Prabowo, Agung dan Sidi Pramono. (2010). Memahat Karakter Melalui Pembelajaran Matematika. Proceedings of The $4^{\text {th }}$ International Conference on Teacher Education; Join Conference UPI \& UPSI Bandung, Indonesia, 8-10 November 2010

Prihandoko. (2006). Pemahaman Dan Penyajian Konsep Matematika Secara Benar Dan Menarik. Jakarta. Depdiknas Ratna Megawangi. 2004. Pendidikan Karakter Social Yang Tepat Untuk Membangun Bangsa. Jakarta: Indonesia Heritage Foundation.

Sumarmo Utari. (2011). Pendidikan Karakter Serta Pengembangan Berfikir Dan Disposisi Matematik Dalam Pembelajaran Matematika. Makalah disampaikan pada seminar pendidikan matematika tanggal 25 februari 2011, NTT.

Suwangsih dan Tiurlina. (2006). Pembelajaran Matematika. Bandung: UPI press.

Zubaedi. (2011). Design Pendidikan Karakter. Jakarta: Kencana Prenada Media Group

Vol. 10 No. 1, Desember 2017

Madrasah homepage: http://ejournal.uin-malang.ac.id/index.php/madrasah/index 